\title{
Obituaries
}

Ronald Charies Ingrey-Senn, formerly Director, Prison Medical Services

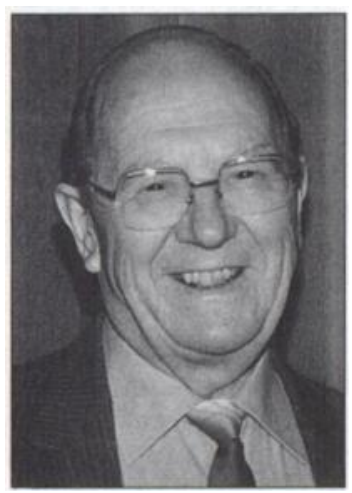

Ronnie, as he was known to everybody, was a man who loved life and lived it to the full. Always filled with fun, he was someone who could always find time to spare for all those he met. Small in stature yet large in personality; a jovial and likeable person.

He was born in London and grew up in Westcliff-on-Sea. He joined the St John Ambulance Brigade as a cadet and decided then to make medicine his career. In 1939 he commenced study for his first MB but soon volunteered to join the RAF. He entered the medical branch and was trained as a laboratory technician. The majority of his service was spent on troop carriers sailing to and from the Far and Middle East. In 1944 he married his wife, Jean, and on demobilisation took up chiropody as a stand-by occupation. In 1951 he returned to Leeds to study medicine and there was awarded the Jamieson Medal for his anatomical dissections. Qualifying MB, ChB in 1957 he held house jobs locally in Yorkshire before coming to London and entering general practice in Clapham.

Ronnie's liking to explore all aspects of life brought him into casual contact with some local prison work in South London. Thereafter, he developed a liking for such a metler and so eventually he decided to make this his ultimate career, Joining the Prison Medical Services as a full-time medical officer at Wandsworth prison in 1968 . He did not serve long at this prison, however, before agreeing to a transfer within the service to Leeds, obviously happy to return to the area of his Alma Mater. Once there he threw himself full heartily into the study of psychiatry, being seconded for a period to Broadmoor before passing his DPM examination. Membership of the College soon followed this and then, still restless to improve his knowledge, he turned his attention to studying for, and passing, the Diploma in Medical Jurisprudence. He was promoted to Senior Medical Officer in charge at Leeds in 1974 and two years later transferred to Prison Department headquarters in London as Assistant Director of all medical services. Then in 1981 he was promoted full Director in charge of the prison medical services, a step regretfully only allowing him two years to hold the post before his time to be retired from the service arrived.

This, however, was by no means the end of Ronnie's working life as he now became a consultant at Leavesden Hospital, involved with the development of its new secure unit. He also became a Mental Health Commissioner, and later a member of the Home Office Parole Board.

When not officially at work, Ronnie remained very active. All his life he persisted with his interest in the St John Ambulance Brigade and eventually, as a consequence of his contribution to that organisation, was made a Knight of the Most Venerable Order of St John of Jerusalem. He was a Ltveryman of Apothecarles' Hall and also was a Freeman of the City of London. This aside, he held high office in the Masonic Order, and also was actively involved in the life of St Albans Abbey which was near to where he then resided. He became President of his local Rotary Club and Chairman of the Governers of a school for children with behavioural problems. He was also Chairman of the St Albans Abbyfield sheltered accommodation for the frail and elderly, and involved in a hostel for the homeless. All in all, he was fully occupied in his spare time in some form of social work or another right up until his untimely death. The diagnosis of carcinoma of the lung Ronnie, as a good Christian, took in his stride without bitterness or despair. Despite increasing pain he remained active and alert throughout, praying with his family until the end. He died peacefully leaving his wife, plus a married son and daughter together with five grandchildren. 
Needless to say he is greatly missed by his family, and by his numerous friends and colleagues.

D. O. T. TOPP

Amedeo Limentani, formerly Consultant Psychiatrist, Portman Clinic, London

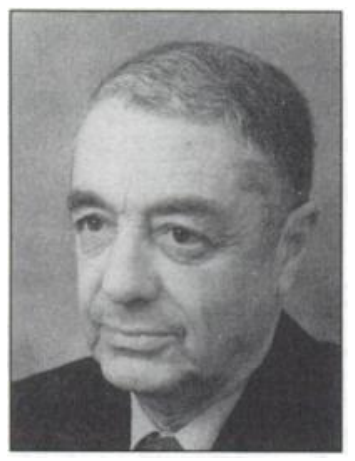

Dr Adam Limentani, the eminent psychoanalyst, died suddenly on Friday 9 September, 1994 after a long illness. He was 81 years old.

Adam Limentani made substantlal contributions to the organisation and functioning of the British PsychoAnalytical Society, initially in the education and training of students and later, as President (to which post he was appointed in 1974), to the overall structure and character of the Society. While he mainly committed his considerable energles to psychoanalysis he was always concerned with its applications in the daily work of psychiatrists and other professionals in the field such as social workers and probation officers.

As President of the International Psychoanalytical Association, to which position he was elected in 1981, he took an active interest in the development of psychoanalysis in many different parts of the world thus contributing fundamentally to the psychodynamic component of psychiatry in Europe, the United States, Canada, the Far East and South America. In recognition of his many contributions to the understanding and treatment of those in need of psychological help he was accorded the rare honour, a few months before his death, of being elected Honorary Vice-President for life of the International Psychoanalytic Association.

Adam Limentani came from a wellestablished Jewish Roman family but emigrated to England in 1938 because of the introduction of racist laws in Italy. He had been an outstanding medical student and subsequently participated in studies to differentiate psychosomatic from neurotic disorders and he had also worked under Cerlett, a ploneer of electro-convulstve therapy.

During the war he worked in the Emergency Medical Service in Mill Hill where the clinical side of the Maudsley Hospital had been evacuated and where he met Aubrey Lewis, whom he acknowledged as an abiding influence throughout his career. From 1941 to 1946 he held a post with the rank of major in the RAMC at a military mental hospital in Talgarth, South Wales.

After appointments at Shenley Hospital, St Bartholomew's Hospital and the Italian Hospital in turn, Limentani, in 1962, received an appointment of consultant psychiatrist at the Portman Clinic. There he became one of the foremost contemporary exponents of international repute, of the psychoanalytic approaches to sexual deviancy and criminality. From his broader psychoanalytic practice, he produced seminal works on clinical issues and problems of technique which had a substantial influence on a wide field of psychoanalysts and psychotherapists. His writings have been translated into many languages. His book, Between Freud and Kletn was published in 1989.

Limentani was first and foremost a clinician and his reputation was such that people from all walks of life, including some from overseas, came to him for treatment. He was remarkably generous to his colleagues: no matter how heavily pressed he would always find time to discuss a colleague's paper with him or to talk over and offer support when an individual was experiencing personal difficulties.

Dr Amedeo Limentani, MD Rome, FRCPsych, DPM, DTM, Honorary Member of the British Psychoanalytic Society, Honorary Archivist and Honorary Vice-President of the International Psychoanalytic Association, was above all a profoundly humane man who cared deeply for those whom he loved and for those whom he could help. He leaves a wife, Denise, and a daughter, Carol.

\section{MerVIn GLasser}

\section{The deathe of the following have also been reported:}

Frank AUtradge BLaADEN, retired Consultant Psychlatrist, 5 Swans Lane, Brant, Broughton. Uncoln.

ELZABETH JEAN DABBS, Consultant Poychiatrist, Blackberry Hill Hospital, Stapleton. Bristol.

Gavin Fumming, formerty Consultant Poychlatrist, Hartwood Hospital, Hartwood, Lanarkshire. 